\title{
Rancang Bangun Alat Perontok Kacang Tanah (Arachis hypogaea L.) Semi Mekanis Tipe Vertikal
}

\section{Design of Vertical Type Semi-Mechanical Peanut (Arachis hypogaea L.) Thresher}

\author{
Ajri Mai Ihsan*, Zul Ariyandi, Sandi Wisaputra, Zulnadi, Amrizal, Fithra Herdian, Mohammad \\ Riza Nurtam, Fanny Yuliana Batubara, Angga Defrian
Program Studi Teknologi Mekanisasi Pertanian, Politeknik Pertanian Negeri Payakumbuh, Indonesia \\ ${ }^{*}$ Penulis Korespondensi \\ Email: ajrimaiihsan@gmail.com
}

\begin{abstract}
Abstrak. Kacang tanah merupakan tanaman polong-polongan yang termasuk dalam golongan komoditi pangan terbesar di Indonesia. Umumnya petani masih menggunakan cara tradisional dalam perontokan kacang tanah sehingga mempunyai kapasitas kecil dan membutuhkan banyak tenaga kerja. Tujuan penelitian ini adalah melakukan rancang bangun alat perontok kacang tanah semi mekanis tipe vertikal yang mempunyai kapasitas besar. Metode penelitian dimulai dari identifikasi masalah dan penyempurnaan ide rancangangan alat perontok kacang tanah. Kemudian dilakukan pembuatan alat, uji fungsional dan uji kinerja. Terakhir dilakukan analisa ekonomi. Hasil uji kinerja alat perontok kacang tanah semi mekanis tipe vertikal diperoleh kapasitas alat $22 \mathrm{~kg} / \mathrm{jam}$, rendemen $41 \%$ persentase kacang tidak terontok $4.44 \%$, presentase buah rusak 4.66\% dan laju pengumpanan $58 \mathrm{~kg} / \mathrm{jam}$. Hasil analisa ekonomi teknik diperoleh break event point (BEP) pengoperasian alat input $284 \mathrm{~kg} /$ tahun dan break event point (BEP) pengoperasian alat output 408,60 kg/tahun.
\end{abstract}

Kata kunci: alat perontok, kacang tanah, semi mekanis

\begin{abstract}
Peanuts are legumes that are among the largest food commodity groups in Indonesia. Generally, farmers still use the traditional method of threshing peanuts so that they have a small capacity and require a lot of labor. The purpose of this study was to design a vertical type semimechanical groundnut thresher tool that has a large capacity. The research method starts with the identification of problems and perfecting the idea of designing peanut thresher tools. Then do the making of tools, functional tests, and performance tests. Lastly, carry out the economic analysis. The results of performance tests of vertical type semi-mechanical groundnut thresher gained 22 $\mathrm{kg} / \mathrm{hour}$ capacity, the yield of $41 \%$ percentage of peanut not threshing $4.44 \%$, percentage of damaged fruit $4.66 \%$ and feed rate of $58 \mathrm{~kg} / \mathrm{hour}$. The results of technical economic analysis obtained the break event point (BEP) operating the input tool $284 \mathrm{~kg} /$ year and the break event point (BEP) operating the output tool $408.60 \mathrm{~kg} /$ year.
\end{abstract}

Keywords: thresher tool, peanut, semi-mechanical 


\section{Pendahuluan}

Benua Amerika, khususnya dari Brazilia merupakan asal dari tanaman kacang tanah (Arachis hypogaea L.) (Suprapto, 2005). Prioritas kedua sering diterima kacang tanah untuk dikembangkan dan ditingkatkan produksinya setelah padi. Meningkatnya kebutuhan pangan, bahan baku industri dan pakan ternak merupakan salah satu hal ini (Sumarno, 1986).

Proses perontokan umumnya dilakukan dengan cara manual menggunakan tangan manusia. Cara ini mempunyai keuggulan dari mutu kacang tanah yang dihasilkan akan berbentuk sempurna dan tidak pecah. Perontokan dengan cara manual memerlukan tenaga kerja yang banyak dan waktu lama. Tenaga kerja yang diperlukan untuk perontokan kacang tanah sekitar $41 \mathrm{HOK} / \mathrm{ha}$ dengan kemampuan kerja perontokan sekitar 2-4 kg polong/jam/orang (Antarno, 1992). Perontokan kacang tanah harus dilakukan secepat mungkin setelah pemanenan yang memilki kadar air polong berkisar 20-24\%. Tetapi jika dipanen lebih awal maka kadar air polong lebih tinggi berkisar 2834\% (Purwadaria, 1991). Iqbal, Suhardi, and Nirisnawati (2018) telah melakukan penelitian mesin perontok multiguna dengan putaran mesin terbaik $2500 \mathrm{rpm}$. Semakin tinggi kecepatan putaran mesin maka tingkat kerusakan gabah juga akan semakin meningkat.

Penelitian ini bertujuan untuk melakukan rancang bangun alat perontok kacang tanah tipe vertikal. Pada mesin ini akan dilakukan analisa kinerja untuk melihat kemampuan dan kapasitas. Pada mesin ini juga dilakukan analisa ekonomi teknik untuk melihat nilai ekonomis.

\section{Bahan dan Metode}

Tabel 1 merupakan daftar bahan bahan yang di perlukan dalam pembuatan alat perontok kacang tanah semi mekanis tipe vertikal.

Tabel 1. Bahan pembuatan alat perontok kacang tanah semi mekanis tipe vertikal

\begin{tabular}{|c|c|c|c|}
\hline No. & Bahan & Spesifikasi & Jumlah \\
\hline 1 & Plat aluminium & $0.7 \mathrm{~mm}$ & $1 / 4$ lembar \\
\hline 2 & Besi Siku & $4 \mathrm{~cm} \times 4 \mathrm{~cm} \times 3 \mathrm{~mm}$ & 1 Batang \\
\hline 3 & Besi poros & $\varnothing 1,9 \mathrm{~cm}$ & $30 \mathrm{~cm}$ \\
\hline 4 & Karet & Benen Mobil & 1 buah \\
\hline 5 & Sporoket dan rantai & Ffg-04-supp-0-20-nfs & $1 \mathrm{set}$ \\
\hline 6 & Bearing UCP & Sbc 204 & 2 Buah \\
\hline 7 & Elektroda & NK 2,6-68 E6013 & $1 \mathrm{~kg}$ \\
\hline 8 & Besi unp & $50 \times 38 \times 2.2 \mathrm{mmx} 6 \mathrm{~m}$ & $60 \mathrm{~cm}$ \\
\hline 9 & Baut dan mur & Hex bolt $3 / 8$ & 12 buah \\
\hline 10 & Paku tembak & Sip, brand $4 \mathrm{mmx} 1,27$ & 30 Buah \\
\hline 11 & Batu grinda & Kinik 4" & 1 buah \\
\hline 12 & Batu grinda potong & White house 4" & 2 buah \\
\hline 13 & Mata bor & Buah & 1 \\
\hline 14 & Cat semprot & Diton & 1 buah \\
\hline 15 & Veleg dan jari-jari & $2,50 \times 17$ & 1 buah \\
\hline 16 & Seng plat & $2 \mathrm{~mm}$ & $50 \mathrm{~cm}$ \\
\hline
\end{tabular}




\section{Metode Penelitian}

Metode penelitian dimulai dari identifikasi masalah dan penyempurnaan ide rancangangan alat perontok kacang tanah. Kemudian dilakukan pembuatan alat, uji fungsional dan uji kinerja. Terakhir dilakukan analisa ekonomi dengan menghitung break event point (BEP). Alur metode penelitian dapat dilihat pada Gambar 1.

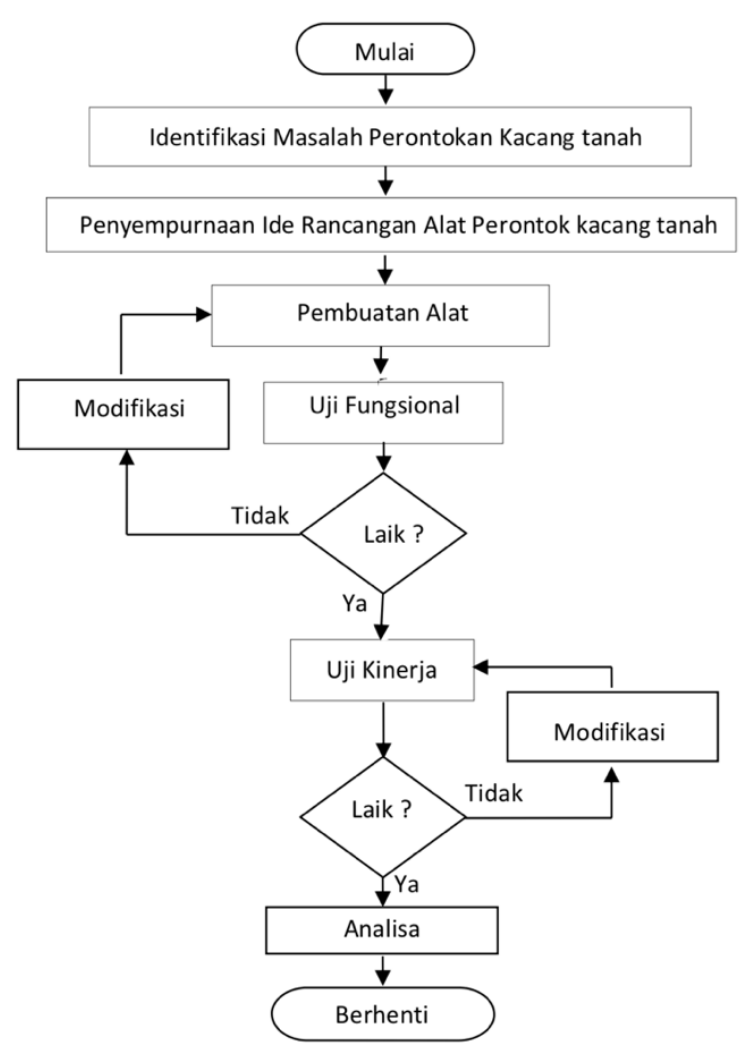

Gambar 1. Diagram alir metode penelitian

\section{Rancangan Alat}

Rancang struktural adalah menjelaskan tentang dimensi atau ukuran dari setiap komponen alat perontok kacang tanah.

Kerangka terbuat dari besi siku yang berukuran $4 \times 4 \mathrm{~cm}$ dengan ukuran panjang $56 \mathrm{~cm}$, tinggi $65 \mathrm{~cm}$, lebar $36 \mathrm{~cm}$ dan memiliki alas dengan menggunakan plat besi $2 \mathrm{~mm}$ dngan ukran 8x8 cm. Adapun gambar rancangan kerangka alat perontok kacang tanah dapat dilihat pada Gambar 2.

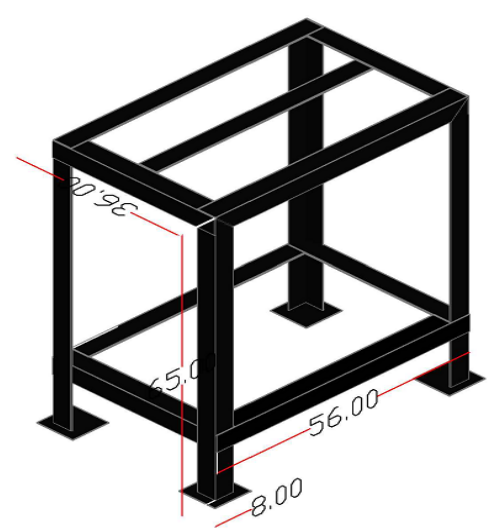

Gambar 2. Kerangka perontok kacang 
Komponen perontok terdiri dari vlag sepeda motor berukuran 17 inci dengan poros 2,5 inci yang sudah di modifikasi dan jari jari sepeda motor berfungsi sebagai mata pisau. Gambar 3 dari roda penggerak.

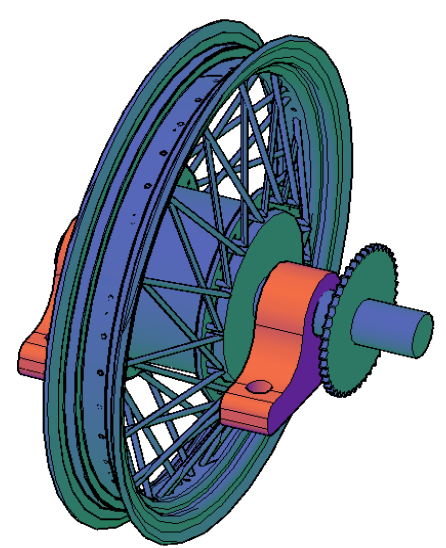

Gambar 3. Bagian vlag dan jari-jari

Inlet merupakan tempat pemasukan kacang yang mau dirontok. Inlet terbuat dari besi plat aluminium dengan tebal $0.7 \mathrm{~mm}$ dengan dimensi yang tertera pada Gambar 4 .

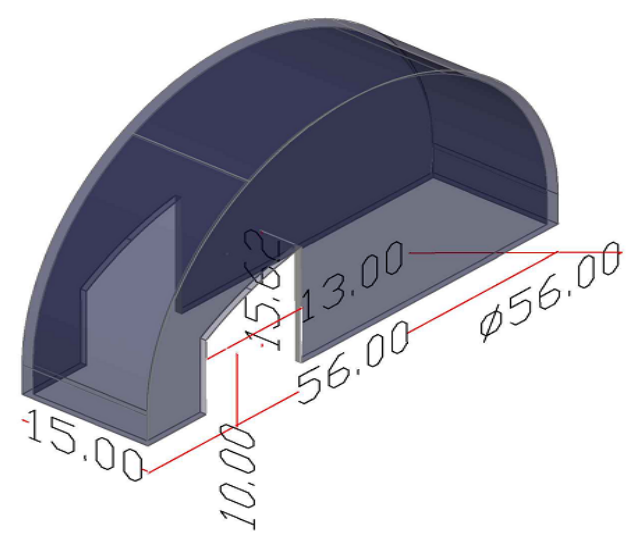

Gambar 4. Bagian inlet

Outlet merupakan bagian untuk tempak pengeluaran dari kacang tanah yang sudah dirontok. Yang terbuat dari besi plat aluminium yang tebal $0.7 \mathrm{~mm}$ dengan dimensi yang tertera pada Gambar 5.

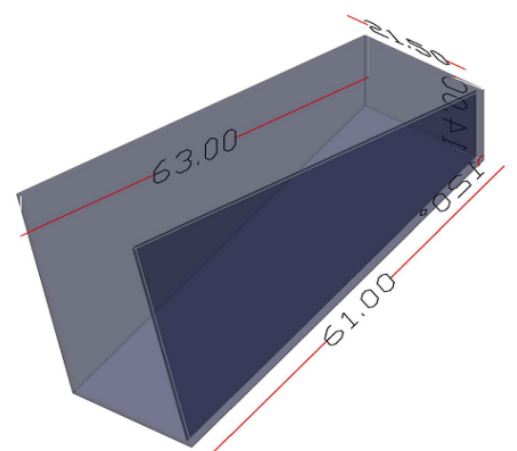

Gambar 5. Bagian outlet 
Sistim penyaluran daya yang berasal dari pegal penggerak, dimana pedal penggerak di injak menggunakan kaki. Pedal penggerak terbuat dari plat siku $3 \times 3 \mathrm{~cm}$ dan plat besi tebal $2 \mathrm{~mm}$, adapun dimensi dapat dilihat pada Gambar 6.

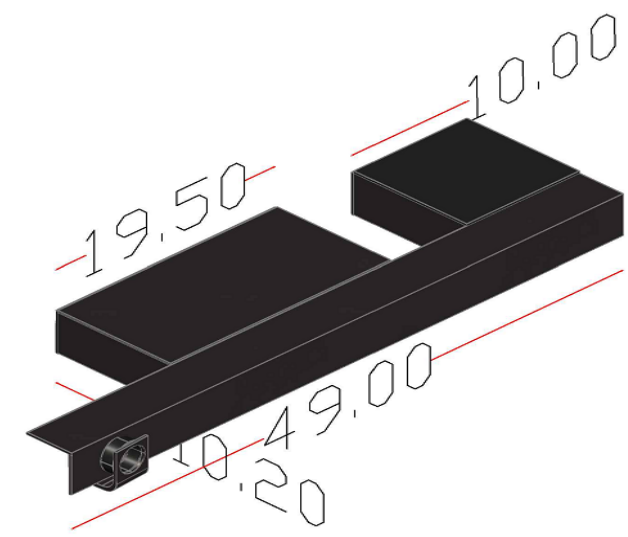

Gambar 6. Bagian pedal penggerak

Pengumpan kacang tanah terbuat dari plat besi yang tebal $2 \mathrm{~mm}$ adapun dimensinya dapat dilihat pada Gambar 7.

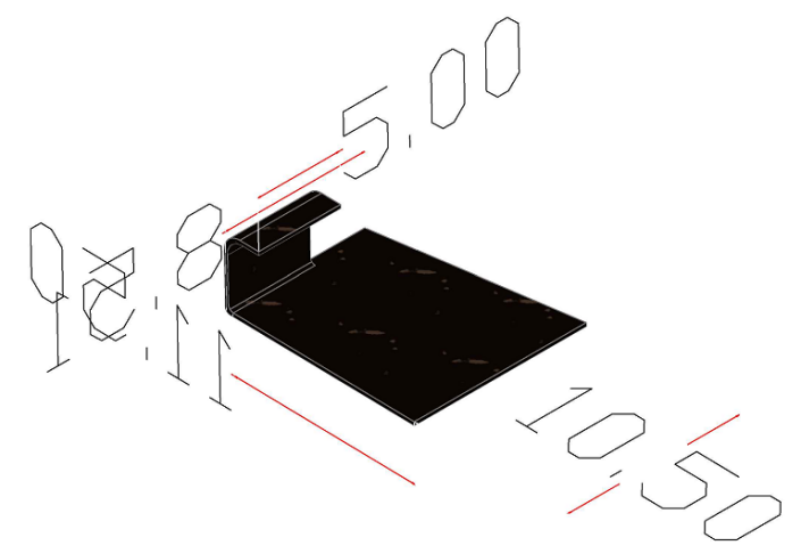

Gambar 7. Bagian pengumpan

Transmisi terdiri dari gear sepeda motor dengan ukuran 5 inci dan rantai yang dihubungkan dengan pedal penggayuh dan karet ban mobil, adapun dimensinya dapat dilihat pada Gambar 8 .

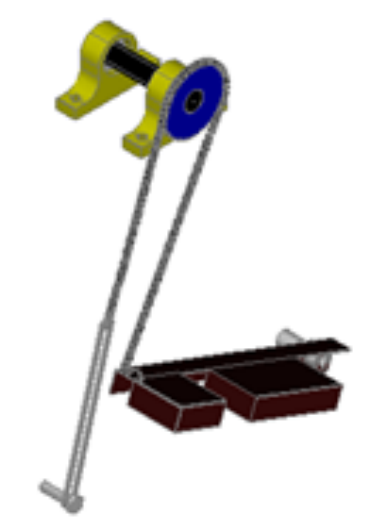

Gambar 8. Transmisi alat

Disain alat perontok kacang tanah semimekanis tipe vertika dapat di lihat pada Gambar 9. 


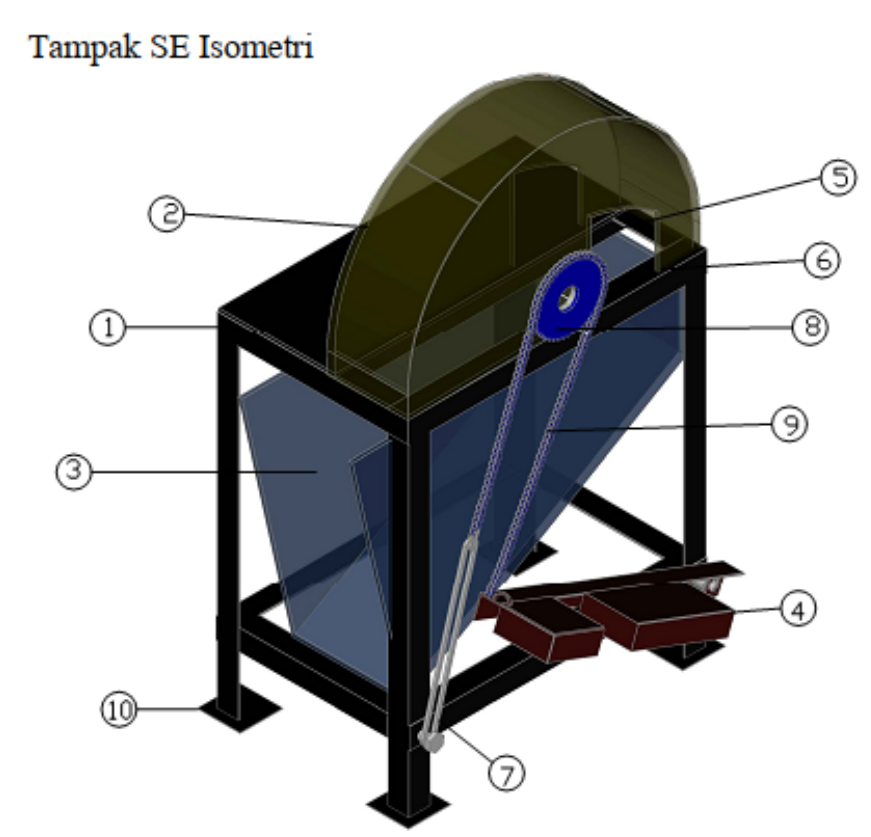

\begin{tabular}{|ll|}
\hline 1. & Kerangka Perontok kacang tanah \\
\hline 2. & Inlet Perontok Kacang Tanah \\
\hline 3. & Outet Perontok Kacang Tanah \\
\hline 4. & Pedal Injak Perontok Kacang Tanah \\
\hline 5. & Veleg Jari-jari Sepeda Motor \\
\hline 6. & Pengumpan Perontok Kacang Tanah \\
\hline 7. & Karet Ban Mobil \\
\hline 8. & Gear Speda motor \\
\hline 9. & Rantai \\
\hline 10. & Alas Perontok Kacang Tanah \\
\hline
\end{tabular}

Gambar 9. Disain alat secara keseluruhan

\section{Prinsip Kerja}

Alat perontok kacang tanah merupkan suatu alat untuk memisah polong kacang tanah dari tangkainnya mengunakan roda dan jari-jari sepeda motor yang sudah di modifikasi sebagi mata perontok polong kacang. Alat ini menggunakan pedal dengan cara diinjak menggunakan kaki sebelah kanan sebagai sumber putaran. Daya putaran yang dihasilkan pedal di salurkan ke poros menuju roda sepeda motor sehingga roda sepeda motor dapat berputar. Pada saaat roda sepeda bergerak maka diambil tangkai kacang tanah dan dekatkan dengan jari-jari sepeda motor, disaat roda berputar maka kacang tanah yang semula ada pada tangkainya satu persatu akan teeontok dari tangkai, setelah terpisah dari tangkainya kacang tanah langsung menuju outlet untuk keluar dari alat.

\section{Hasil dan Pembahasan}

Penelitian ini menghasilkan alat perontok kacang tanah semi mekanis yang mempunyai spesifikasi sebagai berikut:

$\begin{array}{ll}\text { Panjang alat } & : 56 \mathrm{~cm} \\ \text { Lebar alat } & : 36 \mathrm{~cm} \\ \text { Tinggi alat } & : 97 \mathrm{~cm} \\ \text { Kemiringan outlet } & : 30^{\circ} \\ \text { Panjang outlet } & : 61 \mathrm{~cm} \\ \text { Lebar outlet } & : 21.5 \mathrm{~cm} \\ \text { Tinggi outlet bagian belakang } & : 12 \mathrm{~cm} \\ \text { Inggi outlet bagian depan } & : 63 \mathrm{~cm} \\ \text { Pengayuh pedal } & : 49 \mathrm{~cm} \times 10 \mathrm{~cm}\end{array}$



Diameter inlet
$: 56 \mathrm{~cm}$
Lebar inlet
: $15 \mathrm{~cm}$
Lubang pada inlet
: $13 \mathrm{~cm}$
Penyetel laju
: $12 \mathrm{~cm} \times 10.5 \times 8.5$
Berat alat
: $12 \mathrm{~kg}$
Diameter gear
: 5 inc
Diameter tromol
$: 2.5$ inc
Diameter Roda sepeda
$: 17$ inc
Panjang dan lebar karet
: $29 \mathrm{~cm} \mathrm{x} 1.5 \mathrm{~cm}$

Alat perontok kacang tanah semi mekanis tipe vertikal dapat dilihat pada Gambar 10.

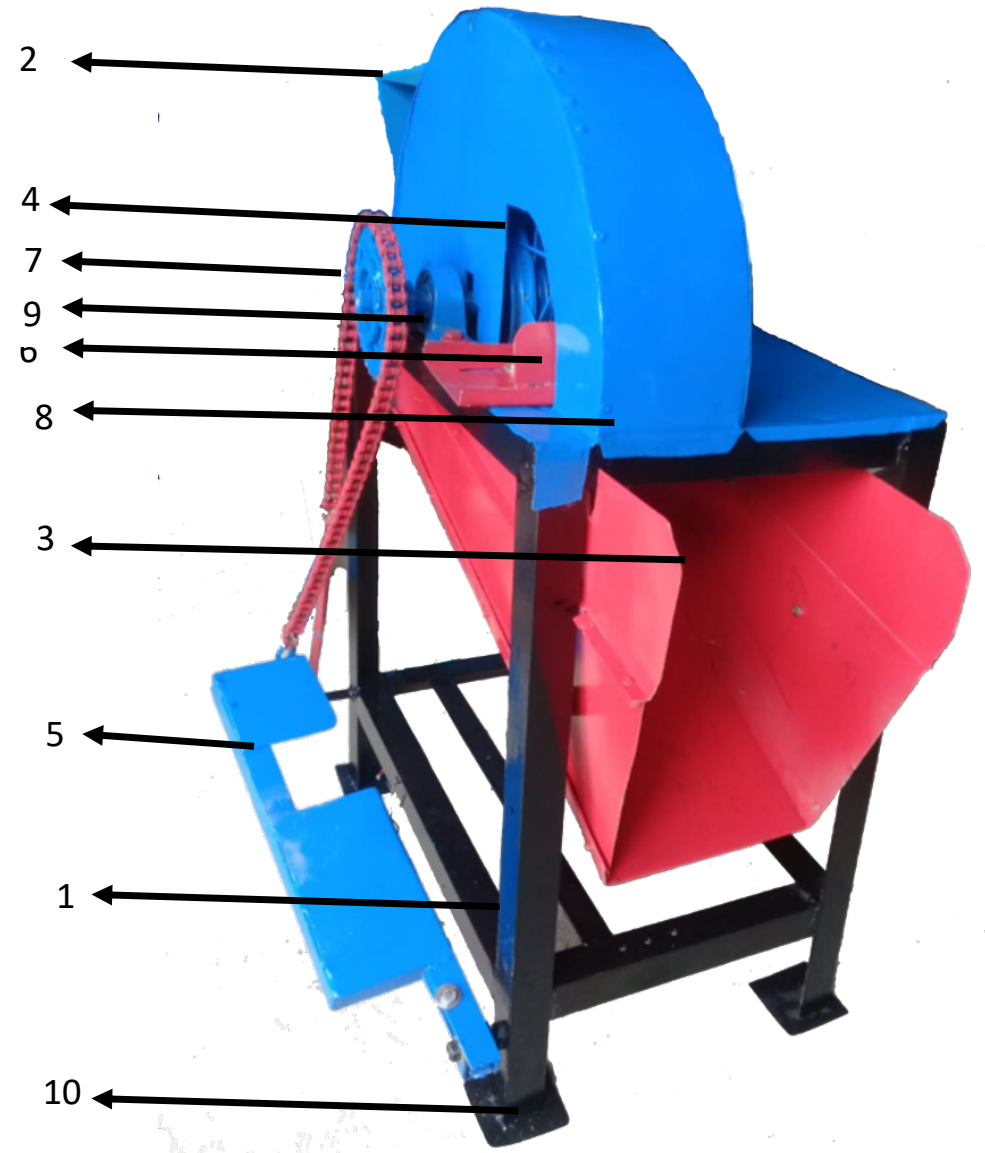

Gambar 10. Alat perontok kacang tanah semi mekanis tipe vertikal

Keterangan gambar:
1. Kerangka
6. Karet ban mobil
2. Inlet
7. Sporket sepeda motor
3. Outlet
8. Pengumpan
4. Roda sepeda
9. Bearing UCV
5. Pedal injak
10. Alas Krangka

\section{Uji Kinerja}

Pengujian alat perontok kacang tanah dilakukan dengan cara 3 (tiga) kali pengujian dan bahan baku untuk pengujian yaitu kacang tanah seberat $8,8 \mathrm{~kg}$. Hasil pengujian alat seperti pada Tabel 1. 
Tabel 1. Hasil pengujian alat perontok kacang tanah semi mekanis tipe vertikal

\begin{tabular}{llrrr}
\hline \multirow{2}{*}{ No } & \multirow{2}{*}{ Uraian } & \multicolumn{3}{c}{ Pengujian } \\
\cline { 2 - 5 } & & 0,5 & \multicolumn{1}{c}{ II } & \multicolumn{1}{c}{ III } \\
\hline 1 & Jarak pengumpan & 3 & 3 & 3 \\
2 & Berat awal (kg) & 0,105 & 0,052 & 0,055 \\
3 & Waktu perontokan (jam) & 1 & 1,09 & 1,19 \\
4 & Berat terontok (kg) & 1,3 & 1,5 & 1,4 \\
5 & Berat tangkai setelah terontok (kg) & 0,2 & 0,1 & 0,1 \\
6 & Berat kacang tidak terontok (kg) & 0,2 & 0,11 & 0,11 \\
7 & Kacang rusak (kg) & 0,3 & 0,2 & 0,2 \\
8 & Berat kacang hilang (kg) & 184 & 235 & 335 \\
9 & RPM & & & \\
\hline
\end{tabular}

Dari Tabel 1 pengujian alat perontok kacang tanah semi mekanis tipe vertikal, maka dapat ditentukan kasitas alat yang dapat dilihat pada Tabel 2.

Tabel 2. Kaspasitas alat perontok kacang tanah semi mekanis tipe vertikal

\begin{tabular}{llrrr}
\hline \multirow{2}{*}{ No } & \multicolumn{1}{c}{ Uraian } & \multicolumn{3}{c}{ Pengujian } \\
& & I & \multicolumn{1}{c}{ II } & \multicolumn{1}{c}{ III } \\
\hline 1 & Kapasitas alat (kg/jam) & 10 & 21 & 22 \\
2 & Rendemen perontokan (\%) & 40 & 40 & 43 \\
3 & Persentase buah kacang tidak terontok (\%) & 6,66 & 3.33 & 3.33 \\
4 & Persentase buah rusak (\%) & 6,66 & 3.66 & 3.66 \\
5 & Laju pengumpanan (kg/jam) & 29 & 58 & 55 \\
\hline
\end{tabular}

\section{Analisa Ekonomi}

Penelitian ini melakukan analisa ekonomi yang bersumber pada Kodoatie (2005) dan telah digunakan pada penelitian: Adam et al., (2020); Novita et al., (2019); Womsiwor et al., (2018) . Dalam analisa biaya alat perontok kacang tanah ini diasumsikan sebagai berikut:

$\begin{array}{ll}\text { Harga jual }(\mathrm{P}) & =\mathrm{Rp} 1.386 .000,- \\ \text { Jumlah jam kerja/hari } & =8 \mathrm{jam} / \mathrm{hari} \\ \text { Perkiraan umur Alat }(\mathrm{N}) & =3 \mathrm{Tahun} \\ \text { Persentase bunga modal/tahun }(\mathrm{I}) & =12 \% / \text { Tahun } \\ \text { Harga akhir }(\mathrm{S}) & =10 \% \times \mathrm{P} \\ \text { Upah operator } & =\mathrm{Rp} .80 .000 / \text { Hari } \\ \text { Jumlah operator } & =2 \mathrm{Orang} \\ \text { Jumlah hari kerja/tahun } & =300 \mathrm{hari} / \mathrm{tahun} \\ \text { Jumlah jam kerja/tahun }(\mathrm{X}) & =2.400 \mathrm{jam} / \mathrm{tahun} \\ \text { Upah/Sewa alat }(\mathrm{R}) & =\mathrm{Rp} .2 .198,-\mathrm{Kg} \\ \text { Kapasitas alat }(\mathrm{C}) & =22 \mathrm{Kg} / \mathrm{Jam}\end{array}$




\section{Biaya tetap}

Biaya tetap merupakan biaya yang independen terhadap waktu pemakaian alat, artinya biaya tetap dikeluarkan walaupun alat dan mesin tidak dioperasikan (Novita \& Anas, 2016). Biaya tetap alat perontok kacang tanah ini meliputi :

Biaya penyusutan (D)

$\mathrm{D}=\frac{\mathrm{P}-\mathrm{S}}{\mathrm{N}}=\frac{\text { Rp. } 1.386 .000,- \text { Rp. } 138.600,}{3 \text { Tahun }}=$ Rp. 415.800/Tahun

Keterangan:

$\mathrm{D}=$ Biaya penyusutan $(\mathrm{Rp} / \mathrm{tahun})$

$\mathrm{P}=$ Harga awal mesin (Rp)

$\mathrm{S}=$ Harga akhir $(\mathrm{Rp}) / 10 \% \times \mathrm{P}$

$\mathrm{N}=$ Perkiraan umur ekonomis (tahun)

Bunga modal (I)

Bunga modal dihitung dengan tujuan untuk memudahkan dalam perhitungan pengembalian nilai modal yang ditanam pada alat atau mesin sehingga Present value dan nilai modal yang ditanam sama.

Bunga modal $=\frac{\mathrm{i}(\mathrm{P})(\mathrm{n}+1)}{2 \mathrm{n}}=\frac{12 \% / \text { Tahun }(\mathrm{Rp} 1.386 .000,-)(3+1)}{2.3 \text { Tahun }}=\mathrm{Rp} 110.880 /$ Tahun

Keterangan:

$\mathrm{I}=$ Bunga modal (Rp/tahun)

$\mathrm{i}=$ Suku bunga bank (\%/tahun)

Biaya tetap $(\mathrm{BT})=$ Biaya penyusutan + Bunga modal

$$
=\text { Rp. 415.800/Tahun }+ \text { Rp110.880/Tahun }=\text { Rp. 526.680/tahun }
$$

\section{Biaya tidak tetap}

Biaya tidak tetap adalah biaya yang dikeluarkan hanya jika alat dan mesin dioperasikan sehingga disebut juga dengan biaya operasi. Jam pemakaian alat dan mesin mempengaruhi biaya ini (Novita \& Anas, 2016).

Upah operator

Upah operator $=\frac{\text { Upah }(\mathrm{Rp}) \times \text { Jumlah operator }}{\text { Jam kerja } / \text { hari }}=\frac{\text { Rp. 80.000/hari } \times 2}{8 \text { jam/hari }}=$ Rp.20.000/Jam

Biaya tidak tetap $($ BTT $)=$ Upah Operator $=$ Rp.20.000/Jam

\section{Biaya Kerja}

$\mathrm{BK}=\frac{\mathrm{BT}}{\mathrm{X}}+\mathrm{BTT}=\frac{\mathrm{Rp} .526 .680 / \text { Tahun }}{2.400 \mathrm{Jam} / \mathrm{Tahun}}+\mathrm{Rp} .20 .000 / \mathrm{jam}=\mathrm{Rp} .20 .220 / \mathrm{Jam}$ 


\section{Biaya Pokok}

Biaya pokok merupakan biaya yang diperlukan oleh suatu alat untuk setiap unit produksi (Novita \& Anas, 2016). Biaya pokok dapat dihitung dengan rumus :

Biaya pokok input

$\mathrm{BP}=\frac{\mathrm{BK}}{\mathrm{LP}}=\frac{\mathrm{Rp} .20 .220 / \mathrm{Jam}}{58 \mathrm{~kg} / \mathrm{jam}}=\mathrm{Rp} .349 / \mathrm{kg}$

Biaya pokok output

$\mathrm{BP}=\frac{\mathrm{BK}}{\mathrm{C}}=\frac{\mathrm{Rp} \cdot 20.220 / \mathrm{Jam}}{22 \mathrm{~kg} / \mathrm{jam}}=\mathrm{Rp} .919 / \mathrm{kg}$

Keterangan:

$\mathrm{BP}=$ Biaya pokok (Rp/buah)

$\mathrm{X}=$ Jumlah jam kerja (jam/tahun)

$\mathrm{C} \quad=$ Kapasitas mesin (buah/jam)

\section{Break event point (BEP) Operasional Alat}

BEP yaitu alat atau mesin yang berada pada kondisi tidak untung dan tidak juga rugi atau kondisi saat jumlah pendapatan sama besar dengan jumlah biaya operasional. Break event point (BEP) operasional alat input

$\mathrm{BEP}=\frac{\mathrm{BT}}{\mathrm{R}-\left(\frac{\mathrm{BTT}}{\mathrm{LP}}\right)}=\frac{\mathrm{Rp} \cdot 526.680 / \text { Tahun }}{\mathrm{Rp} .2 .198 / \mathrm{Kg}-\left(\frac{20.000 / \mathrm{Jam}}{58 \mathrm{~kg} / \mathrm{jam}}\right)}=284 \mathrm{Kg} /$ Tahun

Break Event Point (BEP) Operasional Alat output

$\mathrm{BEP}=\frac{\mathrm{BT}}{\mathrm{R}-\left(\frac{\mathrm{BTT}}{\mathrm{C}}\right)}=\frac{\mathrm{Rp} \cdot 526.680 / \text { Tahun }}{\mathrm{Rp} \cdot 2.198 / \mathrm{Kg}-\left(\frac{20.000 / \mathrm{Jam}}{22 \mathrm{~kg} / \mathrm{jam}}\right)}=409 \mathrm{Kg} /$ Tahun

Keterangan :

$\mathrm{BEP}=$ Break event point (buah/tahun)

$\mathrm{R} \quad=\mathrm{Upah} /$ Sewa alat $(\mathrm{Rp} / \mathrm{buah})$

\section{Kesimpulan}

Alat perontok kacang tanah memiliki panjang $56 \mathrm{~cm}$, lebar $36 \mathrm{~cm}$, tinggi $97 \mathrm{~cm}$, panjang outlet $61 \mathrm{~cm}$, lebar $21,5 \mathrm{~cm}$, diameter inlet $56 \mathrm{~cm}$, lebar inlet $15 \mathrm{~cm}$, diameter gear 5 inci, diameter roda perontok 17 inci, dengan berat alat $12 \mathrm{~kg}$. Berdasarkan uji kinerja alat diperoleh kapasitas alat yaitu $22 \mathrm{~kg} / \mathrm{jam}$, rata-rata rendemen $41 \%$, rata-rata kacang tidak terontok 4.44\%, rata-rata buah rusak $4.66 \%$, laju pengumpanan $58 \mathrm{~kg} / \mathrm{jam}$ dan rata-rata kecepatan sumbu putarnya $252 \mathrm{Rpm}$. Hasil ini lebih besar jika dibandingkan dengan perontokan kacang tanah dengan cara manual yang memilki kapaitas 2-4 kg/jam. Berdasarkan analisa ekonomi yang dilakukan, didapat harga jual alat Rp.1.386.000, dengan biaya pokok input Rp.349/kg, biaya pokok output Rp.919/kg dan break 
event point (BEP) pengoperasian alat input $284 \mathrm{~kg} /$ tahun dan break event point (BEP) pengoperasian alat output 408,60 kg/tahun.

\section{Daftar Pustaka}

Adam, M., Sardino, S., Winaldi, D., Candra, S., Yunika, F., Riko, R., Novita, S., Herdian, F., Hendra, H., \& Laksmana, I. (2020). Rancang Bangun Dan Analisa Alat Pencuci Wortel Tipe Drum. Lumbung, 19(1), 13-29. https://doi.org/10.32530/lumbung.v19i1.199

Antarno. (1992). Pengembangan Mekanisasi Pertanian Dalam Rangka Mempertahankan Swasebada Produksi Beras sampai dengan tahun 2000 di Jawa Timur. 1-11. Risalah Seminar Hasil Pertanian Tanaman Pangan Tahun 1991. Balittan. Malang.

Iqbal, I., Suhardi, S., \& Nirisnawati, S. A. (2018). Uji Unjuk Kerja Alat Dan Mesin Perontok Multiguna (Multipurpose Power Thresher Performance Test). Jurnal Ilmiah Rekayasa Pertanian dan Biosistem, 6(1), 12-16. https://doi.org/10.29303/jrpb.v6i1.73

Kodoatie, R. J. (2005). Analisis Ekonomi Teknik. Penerbit Andi Yogyakarta. Yogyakarta.

Novita S. A. \& A, Irwan. (2016). Buku Kerja Praktek Mahasiswa (BKPM): Alat mesin pasca panen. Payakumbuh, Indonesia: Politeknik Pertanian Negeri Payakumbuh.

Novita, S., Hendra, H., Jamaluddin, J., Makky, M., \& Fahmi, K. (2019). Design and Performance Test of Rubber Grinding Machine. Journal of Applied Agricultural Science and Technology, 3(2), 299-308. https://doi.org/10.32530/jaast.v3i2.112

Purwadaria, H.K. (1991). Teknologi penanganan pasca panen kacang tanah. Pusat Pengembangan Teknologi Enjiniring Pertanian Tepat Guna. Depertemen Pertanian.

Sumarno. (1986). Teknik Budidaya Kacang Tanah. Bandung: Penerbit Sinar Baru.

Suprapto, H.S. (2005). Bertanam Kacang Tanah. Jakarta, Indonesia: Penebaran Swadaya.

Womsiwor, O., Nurmaini, N., Zikri, A., Hendra, H., Amrizal, A., Yudistira, Y., \& Batubara, F. (2018). Rancang Bangun Mesin Pengupas Dan Pencuci Singkong Tipe Horizontal. Journal of Applied Agricultural Science and Technology, 2(2), 11-19. https://doi.org/10.32530/jaast.v2i2.40 